\title{
KÜLÖNÓRÁK AZ ISKOLÁBAN ÉS ISKOLÁN KÍVÜL
}

SZEMERSZKI MARIANNA

$\mathrm{A} z$ iskolai és iskolán kívüli különórák fontos betekintést adnak az árnyékoktatás jelenségének vizsgálatába, jóllehet nem fedik le teljesen e fogalmat. Az Országos kompetenciamérés adatai azt mutatják, hogy az életkor előrehaladtával a hangsúly az iskolán belüli különórákról (korrepetálásokról, szakkörökről, sportkörökről) fokozatosan tolódik el az iskolán kívüli különórák irányába, továbbá megfigyelhető a tanórákon kívüli művészeti és sporttevékenységek arányának fokozatos csökkenése. A tanulmány e jelenségek mögöttes okait járja körül, kitérve az egyes különóratípusok igénybevételének iskolai és egyéni háttértényezőire is.

Kulcsszavakः különórák, Országos kompetenciamérés, szülői háttér

Extra-curricular lessons at school and out-of-school provide important insights into the phenomenon of shadow education, although not fully covering it. Data from the National Assessment of Basic Competencies show that as the age progresses, the emphasis on school activities (tutoring, specializing, sports activities) is gradually shifting towards extra-curricular out-of-school activities, and there is a gradual decline in the proportion of arts and sports activities as well. The research paper explores the underlying causes of these phenomena, including the background factors of students participating in the different types of activities.

Keywords: extra-curricular lessons, National Assessment of Basic Competencies, parental background

\section{Bevezetés}

z iskolai és iskolán kívüli különórák szinte minden országban jelen vannak vala-
milyen mértékben, ugyanakkor kulturális, társadalmi-gazdasági okokkal és az
oktatási rendszer sajátosságaival is összefügg az, hogy egyes térségekben, illetve egyes országokban a különórák mely típusai mennyire jellemzőek. Bár az árnyékoktatás - mint fogalom - manapság széles körben használatos a különórák egyfajta szinonimájaként, érdemes emlékeztetni arra, hogy nem minden tanórán kívüli, illetve iskolán kívüli tanulási forma, készségfejlesztő foglalkozás tartozik ebbe a körbe, másrészről ugyanakkor az is egyértelmű, hogy az árnyékoktatás megannyi jellegzetessége csak az

Levelező szerző: Szemerszki Marianna, 1118 Budapest, Háromszék u. 46/A.

E-mail: mszemerszki@gmail.com 
intézményesült oktatási rendszer sajátosságaihoz viszonyítva értelmezhető (Bray 1999). Struktúrájának, sajátosságainak vizsgálata, a részvételi arányok értelmezése ezért meglehetősen nehéz, s az adott ország oktatási rendszerének ismeretét is feltételezi.

Jelen tanulmányban elsősorban az iskolán kívüli különórák vizsgálatára fókuszálunk, amelyek a 90-es évek eleje óta fokozottan láthatóvá váltak egyes posztszocialista országokban, így Közép- és Kelet-Európa országaiban is (Silova 2010). A vizsgálódást egy adott országon belül is nehezíti a megbízható adatok hiánya, s még inkább érvényes ez a nemzetközi összehasonlításokra: bár a nagy múltú nemzetközi tanulói mérések (PISA, TIMMS) gyưjtenek e témakörhöz kapcsolódóan is információkat, az összehasonlíthatóságot az egyes országok sajátosságain túlmenően esetenként a kérdések eltérő értelmezése is nehezítheti (Bray-Kobakhidze 2014; Entrich 2014). A különórák típusait tekintve a szakirodalomban többféle megközelítéssel találkozunk, amelyek alapján megkülönböztethetünk formájukat tekintve egyéni vagy szervezett, továbbá személyes, online, levelező stb. órákat, míg tartalmilag egyes iskolai tantárgyakra irányuló felzárkóztató (korrepetáló) vagy tantárgyi fejlesztő, gazdagító, továbbá általános készségeket fejlesztő foglalkozásokat, ugyanakkor az adatok terén ilyen mélységü információk gyakran nem állnak rendelkezésre.

A különórák jelenségét a kutatók az utóbbi néhány évtizedben egyre nagyobb intenzitással vizsgálják, megpróbálva megragadni legfőbb sajátosságait, a mögöttes okokat és a tanulmányi eredményre gyakorolt hatásait egyaránt. A legtöbb ország adatai azt mutatják, hogy a tantárgyi jellegü magánkülönórák igénybevétele elterjedtebb középfokon, mint alapfokon, továbbá a városokban is gyakoribb, mint a kisebb településeken. A tanulmányokat kiegészítő tantárgyi különórák jellemzően nem egyenletesen oszlanak meg évfolyamok szerint sem, gyakoribb és nagyobb intenzitású azokon az évfolyamokon, amelyekben a következő iskolafokra való átmenetre készülnek a diákok, különösen ha ez az átmenet vizsgákon alapszik. (Bray 1999.)

A kutatások eltérő eredményekre jutottak a különórák tanulmányi eredményekre gyakorolt hatását illetően: vannak, amelyek a különórák és a jobb iskolai teljesítmény kapcsolatát mutatják, mások szerint a hatás nem szignifikáns, megint mások szerint pedig inkább negatív (Safarzyńska 2013). A hatás nyilvánvalóan erőteljesen függ attól is, hogy milyen célból igénybe vett és milyen típusú különóráról beszélünk, hiszen még az egy adott tantárgyhoz kapcsolódó különórák is szolgálhatnak eltérő célt (lehetnek felzárkóztató, illetve az átlagosnál gyorsabb fejlődést szolgáló, gazdagító jellegűek). A különórák tanulmányi eredményességre gyakorolt hatását azért is nehéz mérni, mert a tanulmányi eredményesség több tényező együttes hatásaként jelentkezik, s a különórákra járók és nem járók karakterisztikája is eltérő.

Nagyon sok kritika éri az iskolán kívüli különórák és különösen sok az árnyékoktatás jelenségét amiatt, hogy negatívan befolyásolhatja az iskolarendszerű oktatást és növeli az oktatási egyenlőtlenségeket. Ez utóbbi kapcsán érdemes felhívni a figyelmet két olyan elméleti megközelítésre, amelyek a magánoktatás jelenségének elméleti háttérmagyarázatát adhatják. Az egyik a kulturális tőke átörökítésének elmélete (Bourdieu 1978), amely szerint a szülők iskolázottsága, társadalmi struktúrában betöltött státusza erőteljesen befolyásolja gyermekük iskolai sikerét vagy sikertelenségét, s az iskolázottabb szülők mindent megtesznek kulturális tőkéjük átörökítése érdekében. Az elméletet a szülői bevonódás elméleti modellje tovább finomítja (Lareau 2000; Reay 2004; ReayBall 1997), amit számos kutató használ az árnyékoktatás jelenségének jobb megértésé- 
hez is (pl. Collas-Jacobs 2013; Park-Byun-Kim 2011), továbbá annak bemutatására, hogy a kulturális háttér és az ahhoz szorosan kapcsolódó eltérő szülői bevonódási minták hogyan függnek össze a tanulók iskolai teljesítményével.

A különórák igénybevétele értelmezhető olyan egyéni (családi) beruházásként is, amely mind egyéni, mind pedig közösségi szinten hasznot eredményez. Reay és Ball elméleti modellje, amely szerint az iskolaválasztásban a munkásosztálybeli és a középosztálybeli szülők eltérő szempontokat érvényesítenek, a racionális döntési modellben is megjelenik. Ezen elmélet szerint az iskoláztatásról való döntés egy költség-haszon kalkuláció eredménye, ami alapján egy alacsonyabb státuszú család számára az iskoláztatás relatív költségei magasabbak, mint a magasabb státuszú családok számára. Emellett az iskolázottabb szülők jobban informáltak a lehetőségekről és jobban is tudják segíteni a gyerekeiket a tanulásban. A középosztálybeli szülőknek több a veszíteni valójuk azzal, ha „lemarad” gyerekük, mert a társadalmi lecsúszást kockáztatják, miközben az alsóbb osztályokban a siker kimenetele bizonytalanabb. (Erikson-Jonsson 1996; BreenGoldthorpe 1997.) Kutatók szerint a racionális döntési modell nem csupán a hagyományos oktatási rendszerben való előrehaladásról hozott döntésekre, hanem az árnyékoktatás igénybevételéről szóló döntésekre is érvényes (Entrich 2015).

Tanulmányunkban két kérdésre keressük a választ. Elsőként leíró adatok segítségével mutatjuk be, hogy milyen különórai részvétel jellemzi a tanulókat a magyarországi iskolarendszer különböző pontjain, majd kiemelten a matematika- és az idegennyelv-különórákra koncentrálva mutatjuk be, hogy mely háttértényezők befolyásolják a részvételt. Arra is választ keresünk, hogy a különórák igénybevétele mutat-e bármilyen összefüggést a szülői bevonódás különböző formáival. Korábbi vizsgálatunkban saját mérési adatokon azt találtuk, hogy a szülői iskolázottság mellett a támogatói szülői háttérnek is hatása volt a tanulói eredményességre (Szemerszki 2015). Ezt kívánjuk megvizsgálni az Országos kompetenciamérés tanulói szinten összekapcsolt adatain is. Ehhez a 2012-ben hatodik évfolyamon tanulókat vesszük alapul, akiknek az előrehaladását kettő, illetve négy évvel későbbi adatokkal összekapcsolva vizsgáljuk. Miután a nyolcadik és a tizedik évfolyam között viszonylag nagy az évismétlés, ezért a 2016. évi 10. évfolyamos adatokat kiegészítjük a 2017. évi adatokkal is, hiszen így a tanulók teljesebb körére kapunk a középiskolai tanulmányokra vonatkozó információkat.

\section{$\mathrm{A} z$ adatok forrása}

$\mathrm{Az}$ adatok összekapcsolása révén egy olyan adatbázis áll rendelkezésünkre, amelyik tanulósorosan mutatja az iskolai életutat. Az összekapcsolás következtében az évek előrehaladtával az elemszám csökken valamelyest a kiinduló elemszámhoz képest, 8. évfolyamra a tanulók 7,7\%-a nem szerepel a két évvel későbbi adatokban (egy részük nyilvánvalóan évismétlés miatt megtalálható későbbi évek adataiban), s 22,8\%-uk a négy évvel későbbi 10. évfolyamos adatbázisban. Ez utóbbi esetben azonban a magas adathiány miatt törekedtünk arra, hogy a tizedik évfolyamos adatok pótolhatók legyenek a 2017ben erre az évfolyamra járók adataival. Ily módon olyanok is bekerültek a harmadik 
hullámba, akik egyébként kimaradtak volna, így a kiinduló populáció 83,8\%-áról lelhető fel valamilyen középiskolai adat (1. táblázat). ${ }^{1}$

1. táblázat: A tanulói szinten összekapcsolt adatbázis elemszámai

\begin{tabular}{lcccc}
\hline & $\begin{array}{c}\text { 2012-ben 6. } \\
\text { évfolyamos }\end{array}$ & $\begin{array}{c}\text { 2014-ben 8. } \\
\text { évfolyamos }\end{array}$ & $\begin{array}{c}\text { 2016-ban 10. } \\
\text { évfolyamos }\end{array}$ & $\begin{array}{c}\text { 2016-ban vagy 2017- } \\
\text { ben 10. évfolyamos }\end{array}$ \\
\hline Fiú & 47456 & 43038 & 35834 & 39215 \\
Lány & 44626 & 41932 & 35263 & 37909 \\
Együtt $(N)$ & 92082 & 84970 & 71097 & 77124 \\
\hline Együtt $(\%)$ & $100,0 \%$ & $92,3 \%$ & $77,2 \%$ & $83,8 \%$ \\
\hline
\end{tabular}

$\mathrm{A} z$ adatok értelmezéséhez fontos áttekinteni a válaszhiányok kérdéskörét is. A tanulók bizonyos, a téma szempontjából releváns adminisztratív jellegü adatai (az iskola típusa, az iskola települése, a tanuló neme, a tanuló lakóhelye, a tanuló hátrányos helyzete és a tanuló matematikaosztályzata) más adatforrásokból teljes körűen hozzákapcsoltak a mérési adatokhoz, ugyanakkor a legtöbb vizsgálni kívánt változó - így a családi háttéradatok és különösképpen a vizsgálni kívánt iskolai és iskolán kívüli különórák igénybevételének adatai - csak a tanulói háttérkérdőívekből nyerhetők ki. A kérdőívek kitöltöttsége ugyanakkor nem teljes, mintegy 83\%-os arányban állnak rendelkezésre. $\mathrm{A} z$ adatok azt mutatják, hogy a háttérkérdőívek kitöltöttségi arányai szignifikáns eltérést mutatnak - a rendelkezésre álló adminisztratív adatokkal kontrollálva - a tanuló neme szerint (a lányok javára), a hátrányos helyzet szerint (a nem ebbe a kategóriába esők javára), illetve a tanulók matematikaosztályzatai szerint (a jobban teljesítők javára). Mindez azt jelenti, hogy valószínüsíthetően a különórákra vonatkozó adatok is valamelyest torzítottak, feltehetően kissé felülreprezentálják a valós arányokat, s még inkább így van ez a tizedik évfolyamos adatokat tekintve.

Amint a bevezetőben jeleztük, az árnyékoktatásnak három lényeges kritériuma van: iskolai tantárgyakra, ismeretekre irányul (azaz nem tartalmazza a zene, sport stb. különórákat), az iskolai oktatást kiegészítő jellege van és fizetett magánoktatást jelent (azaz nem tartalmazza a szülői segítséget, az ingyenes iskolai korrepetálást stb.) (Bray 1999, 2007). Az általunk vizsgált iskolai és iskolán kívüli különórák ${ }^{2}$ egy ennél bővebb kategóriát képviselnek, ugyanakkor adatelemzésünk első részében ezzel a bővebb kategóriával dolgozunk, csak a második részben szükítjük le elemzésünket az iskolán kívüli, egyes tantárgyakhoz kapcsolódó különórák igénybevételére.

1 Összesen tehát 10. évfolyamon 77124 tanuló szerepel az adatbázisban, akiknek 89,6\%-a 2016-ban volt tizedikes, 7,8\%-uk 2017-ben, 2,5\% pedig mindkét évben. Amennyiben valaki mindkét évben 10. évfolyamon tanult, akkor a 2016. évi eredményét és válaszait vettük figyelembe.

2 A kérdőívben az iskolai különórák kapcsán megkülönböztették a felzárkóztató jellegủ és a fejlesztő jellegű foglalkozásokat, továbbá a sportfoglalkozásokat, ugyanakkor az iskolán kívüli különórák esetében tantárgyak, illetve tevékenységtípusok szerint kérdeztek rá a különfoglalkozásokra, a tantárgyi különórák esetében pedig nem azonosítható be, hogy milyen célt szolgálnak. Ezért az iskolán belüli és az iskolán kívüli adatkörök összevetése nem pontos, $\mathrm{s}$ az adatok értelmezését - különösen az árnyékoktatás azonosítása szempontjából - tovább nehezíti, hogy egyes iskolai foglalkozások is lehetnek fizetősek, míg mások ingyenesek. 


\section{Leíró adatok}

Elsőként tehát azt vizsgáljuk meg, hogy az egyes vizsgált évfolyamokon a tanulók milyen arányban vesznek részt iskolai vagy iskolán kívüli délutáni foglalkozásokon. Ehhez az Országos kompetenciamérés tanulói háttérkérdőívének tanulói szinten összevont adatait használjuk, így ugyanannak a tanulói populációnak az iskolai előmenetelét figyelembe véve láthatjuk az idősoros adatokat. Felhívjuk ugyanakkor a figyelmet arra, hogy az adatösszekötés bemutatott módszere következtében a nyolcadik és a tizedik évfolyamos részvételi adatok az országoshoz képest valamelyest felülreprezentáltak, tekintve, hogy a kutatások szerint az iskolarendszerből (így a mi populációnkból is) a kevésbé jó képességű és a kevésbé kedvező szociális hátterű tanulók morzsolódnak le, illetve ismételnek évet nagyobb eséllyel hatodik és tizedik évfolyam között (Szemerszki 2016; Hörich 2019). Mint az előzőekben jeleztük, a háttérkérdőív kitöltöttsége évfolyamonként $83 \%$ körüli, erre a kérdésre pedig átlagosan a tanulók további $2-2,5 \%$-a nem válaszolt, ezért a táblázatokban a válaszadók számát is feltüntetjük. ${ }^{3}$

A válaszadó tanulók körében két tendencia figyelhető meg: az egyik, hogy az iskolai életszakaszokon elörehaladva csökken az iskolán belül igénybe vett különórák aránya, s nem csupán a felzárkóztató és a tehetséggondozó jellegűeké, hanem a sportfoglalkozásoké is. Ezzel párhuzamosan nem nő ugyan összességében az iskolán kívüli különfoglalkozásokon részt vevők aránya, de ez nagyrészt annak tudható be, hogy az életkor előrehaladtával a sport- és művészeti foglalkozások aránya jelentősen visszaesik az iskolán kívül is. A tantárgyi jellegü ${ }^{4}$ magánkülönórák aránya összességében stabilnak mondható, ha csak a matematika és az idegen nyelv tantárgyakat vizsgáljuk, akkor pedig e két tárgy esetében a részvétel növekvő arányokat mutat. Érdemes még egy pillantást vetni azoknak a tanulóknak a különóráira, akik a rendes ütemezéshez képest egy évvel később jutottak el a 10. évfolyamra. Bár egyes esetekben közöttük is lehetnek olyanok, akik nem iskolai eredménytelenség miatt kerültek a szokásos négy év helyett öt évvel később felmérésre, többségében olyanok találhatók itt, akik évet ismételtek a középiskolában, vagy korábban, az általános iskolában, esetleg valamilyen ok miatt évet hagytak ki. A 2017-ben tizedikesek 43\%-a tanul szakképzésben, további 39\%-uk pedig szakgimnáziumban, miközben a 2016-ban tizedikesek körében a megfelelő arányok 16, illetve 36\%. E csoportra az átlagosnál kevesebb különóra jellemző mind az iskolában, mind az iskolán kívül, s a különórákon belül arányaiban kevesebb a tantárgyakhoz kapcsolódó, ezen belül különösen a fejlesztő jellegü foglalkozás (2. táblázat). Mindez előrevetíti a különórák igénybevételének erőteljes társadalmi meghatározottságát, különösen annak bizonyos típusait tekintve. Erre egyébként korábbi évekből is vannak adatok, Ceglédi és Szabó (2014) a tizedik évfolyamos adatokat tanulmányozva egyértelmü összefüggést mutatott ki az iskolán kívüli különórák igénybevétele és a szülők iskolai végzettsége, továbbá a településtípus között. Adataik hasonlóak az általunk

3 Azokat tekintettük válaszadóknak, akik a két kérdés (iskolai különóra, iskolán kívüli különóra) valamelyik alkérdésére válaszoltak. A kérdésre válaszolókat, de egyes alkérdésekre nem válaszolókat az OKM adatbázissal összhangban az adott alkérdés vonatkozásában „nemmel” válaszolóknak tekintettük.

4 Tantárgyi jellegű különórának tekintettünk mindent, ami nem sport-vagy művészeti foglalkozás, ezzel valószínűleg kissé felülbecsülve az arányukat. 
bemutatotthoz (36,9\%-os arány az iskolai foglalkozások és $48 \%$ az iskolán kívüli foglalkozások esetében). ${ }^{5}$

2. táblázat: Iskolán belüli és iskolán kívüli különórák igénybevételi arányai az adott kérdésre válaszolók körében (az egyéni szinten összekapcsolt adatbázis alapján, \%)

\begin{tabular}{lcccc}
\hline & $\begin{array}{c}\text { 2012-ben 6. } \\
\text { évfolyamos }\end{array}$ & \begin{tabular}{c} 
Közülük \\
\cline { 3 - 5 }
\end{tabular} & \multicolumn{4}{c}{ évfolyamos } & $\begin{array}{c}\text { 2016-ban 10. } \\
\text { évfolyamos }\end{array}$ & $\begin{array}{c}\text { 2017-ben } 10 . \\
\text { évfolyamos }\end{array}$ \\
\hline$N$ & 75802 & 68453 & 57393 & 5689 \\
Korrepetálás, fejlesztö foglalkozás & 34,4 & 29,9 & 18,2 & 18,7 \\
Tehetséggondozó, fejlesztő & 20,0 & 20,8 & 9,7 & 4,6 \\
foglalkozás & 43,2 & 33,9 & 19,4 & 17,2 \\
Sportfoglalkozás & 71,5 & $\mathbf{6 3 , 1}$ & 39,5 & $\mathbf{3 4 , 2}$ \\
\hline Együtt & 49,8 & 46,1 & 26,2 & 22,0 \\
\hline Ezen belül: tantárgyi jellegü & & Iskolán kívüli részvétel & \\
\hline & 75883 & 68808 & 57718 & 5733 \\
\hline$N$ & 13,2 & 15,8 & 18,8 & 12,7 \\
Matematika-különóra & 13,8 & 14,7 & 17,8 & 7,7 \\
Idegennyelv-különóra & 13,6 & 9,8 & 6,7 & 3,5 \\
Zenei különóra & 36,5 & 32,8 & 28,5 & 19,6 \\
Sportfoglalkozás & 16,6 & 13,1 & 9,1 & 8,1 \\
Egyéb különóra & $\mathbf{5 8 , 7}$ & $\mathbf{5 4 , 6}$ & $\mathbf{5 1 , 9}$ & $\mathbf{3 5 , 4}$ \\
\hline Együtt & 34,5 & 33,5 & 35,5 & 23,0 \\
\hline Ezen belül: tantárgyi jellegü & & & &
\end{tabular}

$\mathrm{Az}$ 1. ábra szemléletesen mutatja a délutáni foglalkozásokon részt vevők arányait az egyes évfolyamokon: míg hatodik osztályban a kérdőívre válaszoló tanulóknak mindöszsze 13,8\%-a nem vett részt semmilyen délutáni foglalkozáson, addig tizedik évfolyamra e csoport aránya 36\%-ra nő, ezzel párhuzamosan pedig a csak iskolai foglalkozásokon részt vevők aránya jelentősen csökken.

A hatodik évfolyamos adatok azt mutatják, hogy az iskolai, illetve iskolán kívüli délutáni foglalkozások igénybevétele szignifikáns összefüggést mutat a tanuló iskolai jellemzőivel (iskola típusa, tanulmányi eredmény), a családi háttér jellemzőivel (lakóhely, szülők iskolai végzettsége, anyagi helyzet, hátrányos helyzet), továbbá számos olyan

5 Az eltérés nem feltétlenül jelent növekedést 2006-hoz képest, tekintve, hogy a mi adataink egy szelektáltabb populációra vonatkoznak. Ugyanakkor míg a legtöbb esetben az egyes foglalkozástípusok arányai is nagyon hasonlóak, érdekes elmozdulásnak tekinthető, hogy míg 2006-ban a tizedikesek 22,9\%-a vett részt iskolai sportfoglalkozáson és 23,2\%-a iskolán kívülin, addig a 2016. évi Országos arányok 19,3\%, illetve $27,2 \%$ voltak, ami azt jelenti, hogy a középfokon tanulók körében egyes sportfoglalkozások színtere áttevődött a nem iskolai színhelyekre. 


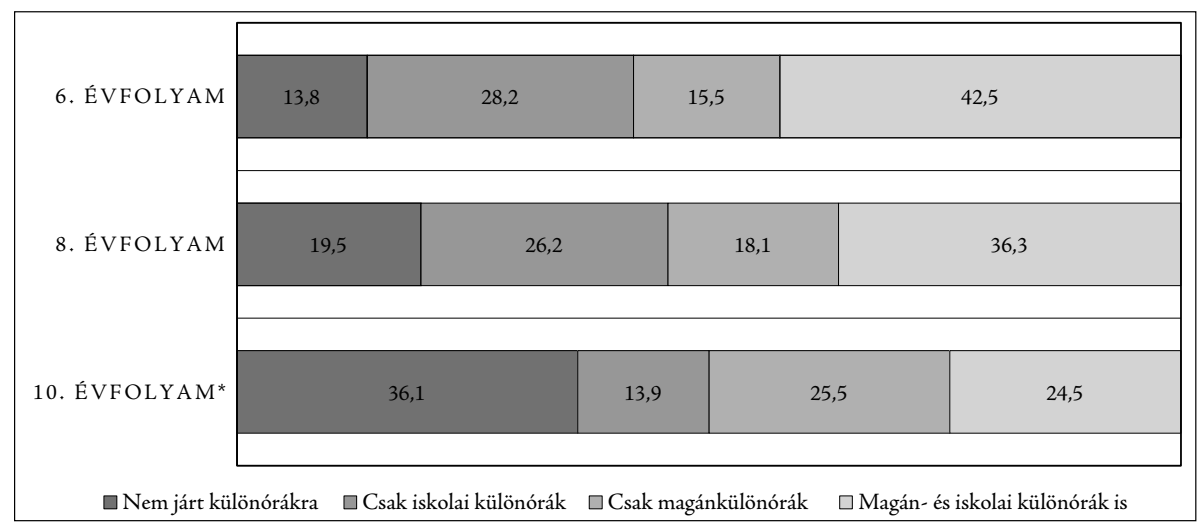

1. ábra: Külön foglalkozásokon való részvétel a válaszadók körében - egyéni szinten összekapcsolt adatbázis (\%). * A 2016-ban vagy 2017-ben 10. évfolyamra járók összevont adata

háttértényezővel, amelyek a gyermekek tanulási útjának a szülők általi egyengetését és a nagyobb fokú szülői bevonódást mutatják (körzetes iskolába jár-e a gyermek, milyen gyakran segít az iskolai feladatokban a család, milyen gyakran beszélnek gyermekükkel az iskoláról). (Melléklet 1. táblázat.) Minél kedvezőbb az előbbiekben felsorolt változók értéke, annál valószínűbb, hogy a tanuló részt vesz valamilyen különórán, s annál valószínübb, hogy annak az iskolán kívüli formáit (is) választja. A szignifikáns háttérváltozók között a racionális döntéshozatalra utalót is felfedezhetünk, nevezetesen a tanuló továbbtanulási ambícióit. Miután a továbbtanulási tervek ebben az életkorban még feltehetőleg a szülők által erőteljesen befolyásoltak (ráadásul a tanulói háttérkérdőív kitöltésében a szülők is segíthetnek, tehát a válaszok feltehetően részben eleve az ő véleményüket tükrözik), ezt felfoghatjuk ennek az egyik indikátoraként, amely arra utal, hogy azok a családok, amelyekben a gyereküket legalább érettségiig, de főleg felsőfokra kívánják eljuttatni, sokkal gyakrabban járatják gyermekeiket valamilyen iskolán kívüli különórára.

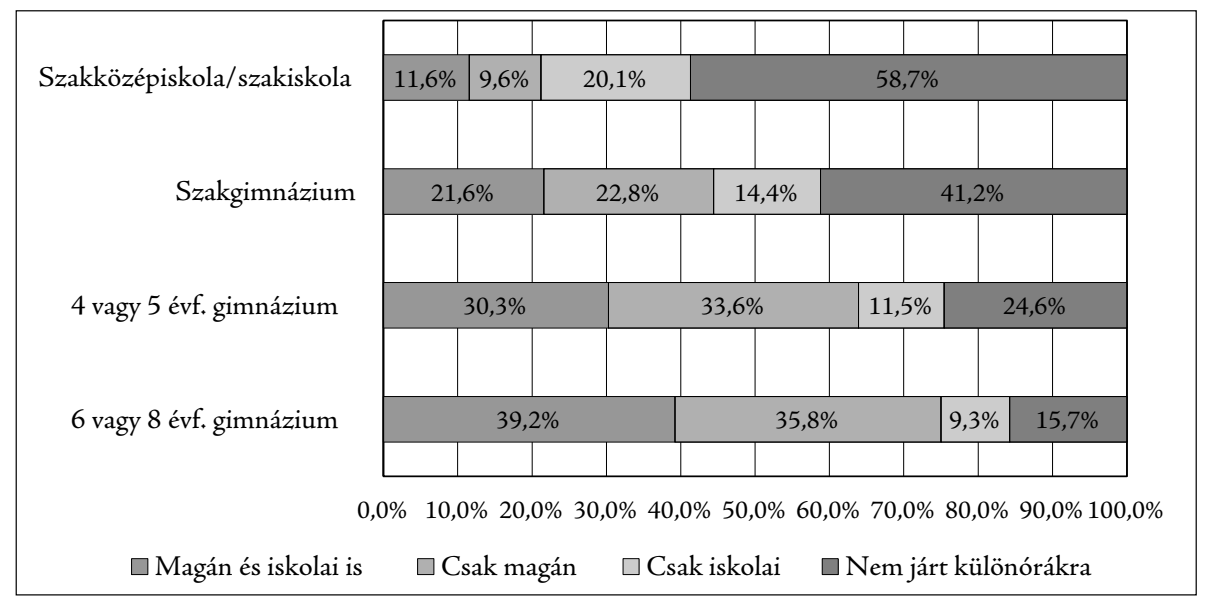

2. ábra: Külön foglalkozásokon való részvétel tizedik évfolyamon képzési típus szerint - egyéni szinten összekapcsolt adatbázis (a válaszadók körében, $N=62845$, \%) 
A tizedik évfolyamon látványosan kirajzolódnak a képzési típus szerinti eltérések is: míg a gimnazisták túlnyomó többsége jár valamilyen délutáni iskolán kívüli foglalkozásra, s nagyon sokan emellett iskolaira is, addig a szakgimnáziumokban tanulóknak 60\%-a vesz igénybe valamilyen délutáni foglalkozást, a szakközépiskolás és szakiskolai tanulóknak pedig kevesebb mint a fele. Részleteiben megvizsgálva az adatokat, az is látszik, hogy ezek többségében iskolai vagy iskolán kívüli sportfoglalkozások, illetve korrepetáló jellegü iskolai foglalkozások (2.ábra).

\section{Matematika- és idegennyelv-különórák}

Az előzőekben láthattuk, hogy az iskolán kívüli különórák típusaikat tekintve vegyes jellemzőkkel bírnak, megtalálhatók közöttük a tantárgyi jellegűek, illetve a készségeket fejlesztők egyaránt, ezért a tanulmány utolsó részében két tantárgyhoz kapcsolódó különórára, a matematikára és az idegen nyelvre fókuszálva mutatjuk be azt, hogy iskolán kívüli igénybevételük milyen háttértényezőkkel mutat összefüggést, s kimutatható-e azoknak a későbbi iskolai útra gyakorolt hatásuk. Korábban már láthattuk, hogy hatodik évfolyamon e két tantárgyi különóra igénybevételi aránya közel azonos, de közelebbről is megvizsgáljuk őket, amennyire adataink ezt engedik.

A matematika tantárgy esetében rendelkezésre áll az előző félévi matematikajegy az adatbázisban, az idegen nyelv esetében azonban csak az összesített előző félévi tanulmányi átlaggal számolhatunk. Ugyanakkor ez alapján is szembetűnő a két különóra közötti funkcionális különbség: míg a matematika esetében vegyes használatról beszélhetünk ugyan, de azon belül inkább a felzárkóztató, korrepetáló jelleg tűnik hangsúlyosabbnak (erre utal az igénybevétel összefüggése a matematikajeggyel és a tanulmányi átlaggal egyaránt), addig az idegen nyelv esetében a különóra igénybevétele a jobb tanulmányi eredménnyel rendelkezők körében jellemző, tehát inkább gazdagító, fejlesztő, kiegészítő jellegünek tekinthető (nem is feltétlenül az iskolában tanult idegen nyelvből) (3. táblázat). Ezt az is mutatja, hogy a 8 osztályos gimnáziumokba járó, képességek és társadalmi háttér szerint is szelektáltabb tanulói körben az iskolán kívüli idegennyelv-oktatás igénybevétele

3. táblázat: Az idegennyelv- és matematika-különórákra, magánórákra járók aránya egyes tanulói csoportokban a 6. évfolyamon* (\%)

\begin{tabular}{llcc}
\hline & & $\begin{array}{c}\text { Idegen nyelv } \\
N=75613\end{array}$ & $\begin{array}{c}\text { Matematika } \\
N=75591\end{array}$ \\
\hline Az iskola típusa & Általános iskola & 13,5 & 13,2 \\
& $\begin{array}{l}\text { 8 évfolyamos } \\
\text { gimnázium }\end{array}$ & 21,5 & 14,3 \\
\hline A tanuló előző félévi & nincs adat & 9,7 & 13,8 \\
matematikajegye a központi & 1 & 4,7 & 13,9 \\
adatbázis alapján & 2 & 6,6 & 18,2 \\
& 3 & 10,7 & 16,0 \\
& 4 & 15,9 & 12,4 \\
& 5 & 20,5 & 7,7 \\
\hline
\end{tabular}


3. táblázat: $\left(f_{\text {folyt. }}\right)$

\begin{tabular}{|c|c|c|c|}
\hline & & $\begin{array}{c}\text { Idegen nyelv } \\
N=75613\end{array}$ & $\begin{array}{l}\text { Matematika } \\
N=75591\end{array}$ \\
\hline \multirow{6}{*}{$\begin{array}{l}\text { A tanuló előző félévi tanulmányi } \\
\text { átlageredménye }\end{array}$} & 3 -as alatti & 5,5 & 14,1 \\
\hline & $3,0-3,5$ & 8,7 & 15,2 \\
\hline & $3,6-4,0$ & 11,7 & 14,8 \\
\hline & $4,1-4,5$ & 15,8 & 13,0 \\
\hline & 4,5 feletti & 21,5 & 9,8 \\
\hline & nem derül ki & 10,9 & 15,2 \\
\hline \multirow[t]{4}{*}{ A tanuló lakóhelyének típusa } & Budapest & 16,7 & 14,1 \\
\hline & megyeszékhely & 17,1 & 14,9 \\
\hline & más város & 14,5 & 14,5 \\
\hline & község & 10,5 & 11,0 \\
\hline \multirow[t]{2}{*}{ A tanuló neme } & lány & 14,3 & 13,8 \\
\hline & fiú & 13,3 & 12,7 \\
\hline \multirow[t]{5}{*}{$\mathrm{A} z$ anya iskolai végzettsége } & legfeljebb 8 általános & 5,0 & 9,2 \\
\hline & szakmunkásképző & 9,2 & 13,9 \\
\hline & érettségi & 15,8 & 13,8 \\
\hline & felsőfok & 23,9 & 14,8 \\
\hline & nem derül ki & 10,4 & 15,0 \\
\hline \multirow[t]{5}{*}{$\mathrm{A} z$ apa iskolai végzettsége } & legfeljebb 8 általános & 5,1 & 9,8 \\
\hline & szakmunkásképző & 10,9 & 13,3 \\
\hline & érettségi & 17,8 & 14,4 \\
\hline & felsőfok & 24,1 & 14,7 \\
\hline & nem derül ki & 10,0 & 12,9 \\
\hline Összesen & & 13,8 & 13,3 \\
\hline
\end{tabular}

${ }^{*}$ Valamennyi összefüggés szignifikáns $(p \leq 0,001)$

másfélszerese az általános iskolákba járókénak, míg a matematika esetében jóval kisebb az eltérés.

$\mathrm{A} z$ adatokat azokra megvizsgálva, akikről mind a három tanévre rendelkezésre áll információ, azt találjuk, hogy a matematika esetében 11,8\% legalább két évfolyamon jelölte, hogy részt vett különórán, míg további $20 \%$ egy tanév esetében, idegennyelv-különórára pedig legalább két tanévben 12,2\% járt, s 19,1\% jelölte egy tanév esetében a részvételét. Összesen tehát a válaszadó tanulók közel egyharmada volt érintett legalább a tanulmányai egy-egy szakaszában a két vizsgált tantárgyi különórában. Ez az adat azonban valószínúleg valamelyest felülbecsüli a tényleges arányokat, tekintve, hogy a háttérkérdőíveket kitöltők valamennyi évfolyamon kissé felülreprezentáltak a magasabb státuszú és a jobb képességű tanulók között, akik esetében a különórai részvétel magasabb.

A matematika- és idegennyelv-különórákon való részvétel 10. évfolyamon ugyanebben a tanulói csoportban (tehát azok között, akik 2012-ben voltak hatodikosok és 2016-ban 


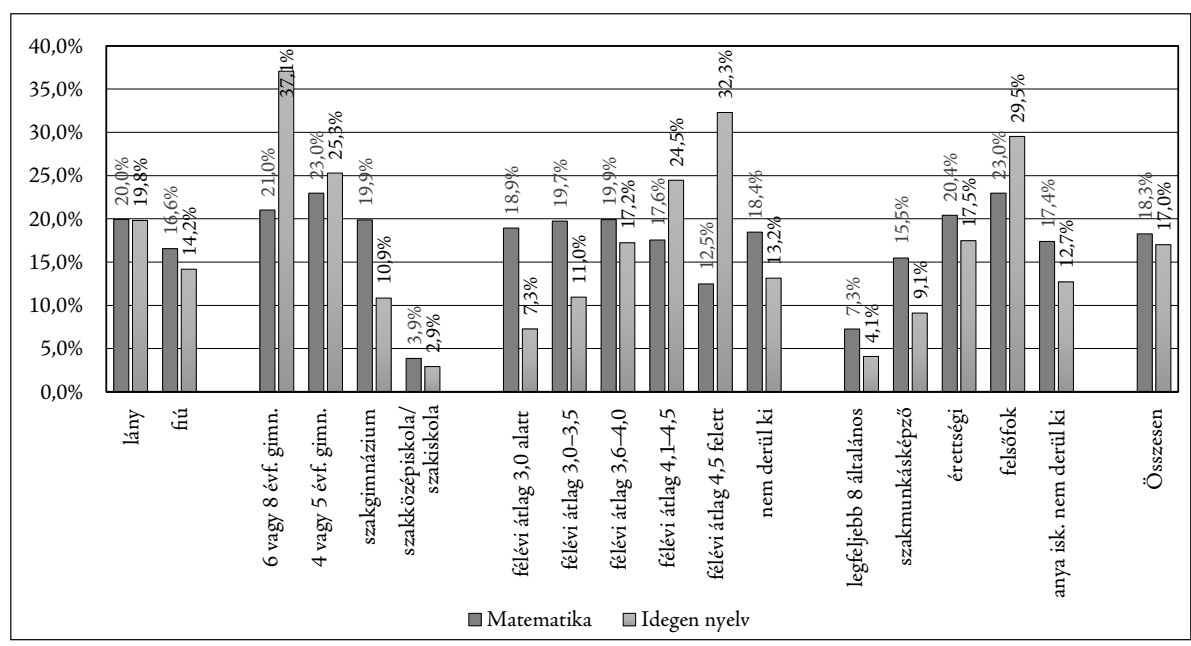

3. ábra: Az idegennyelv- és matematika-különórákra, magánórákra járók aránya néhány háttérjellemző szerint 10. évfolyamon az összevont adatbázisban* (\%). *Valamennyi összefüggés szignifikáns $(p \leq 0,001)$

vagy 2017-ben tizedikesek) már mutat némi eltérést a hatodikos adatokhoz képest. A nemek szerinti eltérés nagyobb: mindkét tantárgyból a lányok járnak nagyobb arányban különórákra. Ugyanígy, még inkább markánssá vált a szülők (3. ábránkon az anya) iskolai végzettsége szerinti eltérés is, s újdonságként hat, hogy tizedik osztályban ez már a matematika tantárgy esetében is kifejezettebb. Feltehetően ugyanakkor ez legalább részben az iskolatípusok szerinti erőteljes szelekció hatása, hiszen képzési típusok szerint is eltér a matematika-különórákra járók aránya, más kutatásokból pedig azt is tudjuk, hogy az egyes középfokú képzésekre járó tanulók családi háttere jelentősen eltér (Andor-Liskó 1999; Szemerszki 2015). Az idegennyelvi-különórák esetében még hangsúlyozottabb a képzési típus és a szülői iskolázottság szerinti eltérés, s egyértelmű a tanulók iskolai eredményeivel való összefüggés is, ami ugyanakkor nem függetleníthető az előbbi két háttértényezőtől.

Hogy a hatásokat jobban elkülöníthessük, logisztikus regresszióval vizsgáltuk meg a háttérváltozók különórák igénybevételére gyakorolt hatásait tizedik osztályban. Függő változóként az egyes modellekben a tizedik osztályos különórákon való részvételt, míg független változóként a tanuló nemét, iskolatípusát, félévi eredményét és az anya iskolai végzettségét szerepeltettük. Ezenkívül bevettük a modellbe azt is, hogy a tanuló milyen iskolai végzettséget szeretett volna elérni, amikor 6. osztályos volt.

A modellekből jól látható, hogy az idegen nyelv tanulása esetében nagyobbak a családi háttérhez kapcsolódó hatások, s a nyelvi különórák igénybevételének esélyét 1,7-szeresére növeli az is, ha a tanulónak diplomaszerzési ambíciói mutatkoztak már a 6. osztályban. Ez utóbbi azonban a tizedikes matematika-különórák igénybevétele esetében jóval kisebb hatást mutat. Szembetűnő még a két modell közötti eltérés abban a tekintetben is, hogy míg a matematika esetében a szakgimnáziumokba járók részvételének az esélyhányadosai alig maradnak el a gimnáziumokba járókétól, az idegennyelv-különórákat kétszer olyan nagy eséllyel veszik igénybe a gimnazisták, mint a szakgimnazisták. A különbséget indokolhatja az, hogy a matematika egységesen kötelező érettségi tantárgy, míg az idegen 
nyelv iskolán kívüli tanulása nem feltétlenül jelenti az iskolában tanult nyelv(ek)ből teendő érettségi vizsgára való felkészülést, hanem jelentheti másik nyelv tanulását is magántanárnál vagy nyelvtanfolyamon, ugyanakkor az eltérés az eltérő iskoláztatási törekvéseknek is betudható, amint arra korábban is utaltunk. Mindkét modellben látható, hogy a fiúk különórákon való részvételi esélyei minden más háttérváltozó kontroll alatt tartása mellett is kisebbek, mint a lányoké (4. táblázat).

4. táblázat: Az idegennyelv- és matematika-különórák, magánórák igénybevétele a 10. évfolyamon - A bináris logisztikus regressziós modell esélyhányadosai

\begin{tabular}{|c|c|c|c|}
\hline & & $\begin{array}{l}\text { Idegen nyelv } \\
(N=75603)\end{array}$ & $\begin{array}{c}\text { Matematika } \\
(N=75591)\end{array}$ \\
\hline & & $\operatorname{Exp}(B)$ & $\operatorname{Exp}(B)$ \\
\hline A tanuló neme (ref.: lány) & fiú & $0,823^{* * *}$ & $0,778^{* * *}$ \\
\hline \multirow{5}{*}{$\begin{array}{l}\text { Félévi tanulmányi átlag 10. évfolya- } \\
\text { mon (ref.: } 3 \text {-as alatt) }\end{array}$} & $3,0-3,5$ & $1,179^{* * *}$ & $0,844^{* * *}$ \\
\hline & $3,6-4,0$ & $1,371^{\star * *}$ & $0,649^{* * *}$ \\
\hline & $4,1-4,5$ & $1,588^{\star * *}$ & $0,445^{* * *}$ \\
\hline & 4,5 feletti & $1,823^{* * *}$ & $0,257^{* * *}$ \\
\hline & nem derül ki & 1,077 & $0,646^{* * *}$ \\
\hline \multirow{4}{*}{$\begin{array}{l}\text { Az anya iskolai végzettsége (ref.: } \\
\text { legfeljebb } 8 \text { osztály) }\end{array}$} & szakmunkásképző & $1,653^{* * *}$ & $1,656^{* * *}$ \\
\hline & érettségi & $2,284^{* * *}$ & $1,970^{* * *}$ \\
\hline & felsőfok & $3,210^{\star * *}$ & $2,297^{* * *}$ \\
\hline & nem derül ki & $2,209^{* * *}$ & $1,840^{* * *}$ \\
\hline \multirow{3}{*}{$\begin{array}{l}\text { Az elérni kívánt iskolai végzett- } \\
\text { ség 6. évfolyamon (ref. legfeljebb } \\
\text { szakmunkásképző) }\end{array}$} & érettségi & 1,147 & 1,115 \\
\hline & felsőfok & $1,734^{* * *}$ & $1,250^{\star * *}$ \\
\hline & nem derül ki & $1,711^{* * *}$ & $1,210^{*}$ \\
\hline \multirow{3}{*}{$\begin{array}{l}\text { A középiskola típusa 10. évfolyamon } \\
\text { (ref.: szakközépiskola/szakiskola) }\end{array}$} & 6 vagy 8 évf. gimn. & $6,419^{* * *}$ & $6,635^{* * *}$ \\
\hline & 4 vagy 5 évf. gimn. & $4,357^{* * *}$ & $6,941^{* * *}$ \\
\hline & szakgimnázium & $2,482^{* * *}$ & $5,145^{* * *}$ \\
\hline \multirow[t]{4}{*}{ Modellstatisztikák } & Constant & 0,018 & 0,047 \\
\hline & -2 Log likelihood & 46210,187 & 51043,796 \\
\hline & Cox $\&$ Snell $R$ Square & 0,104 & 0,058 \\
\hline & Nagelkerke $R$ Square & 0,173 & 0,095 \\
\hline
\end{tabular}

A szignifikanciaszint jelölése ${ }^{*} p<0,05,{ }^{* *} p<0,01,{ }^{* * *} p<0,001$

Úgy tűnik tehát az előző modellekből, hogy a tanulók iskoláztatásával kapcsolatos korai terveknek hatásuk van a későbbi különórák igénybevételére is, ezért végezetül azt vizsgáljuk meg, hogy a szülői bevonódás egyéb faktorainak lehet-e szerepük abban, ha a tanuló már 6. évfolyamon is különórára jár. A Melléklet 1. táblázatában szereplő adatok szerint szignifikáns összefüggés van az iskolán kívüli különórák igénybevétele és a szülői bevonódás egyes háttérváltozói között (segítségnyújtás a házi feladatban, beszélgetés az iskoláról, nem körzetes iskolába való beíratás). Arra vagyunk kíváncsiak, 
hogy a modellben ezek az összefüggések más háttérváltozókkal kontrollálva is érvényesülnek-e.

A hatodik évfolyamos adatokon tehát azt vizsgáljuk meg, hogy mekkora eséllyel vesznek részt az adott különórán az egyes csoportokba tartozó tanulók. Ehhez logisztikus regressziós modellt használunk külön a két különóratípusra. A bevont változók egy része a tanuló attribútumait képezi le (a gyermek neme, tanulmányi eredménye, iskolatípus), míg mások a családi háttér jellemzőit hivatottak megjeleníteni (anya és apa iskolázottsága, anyagi helyzet szubjektív mutatója, településtípus). Miután a különórák választása családi döntés eredménye, a családi háttéradatok mellett oly módon válogattuk ki az adatbázisból a háttértényezőket, hogy azok a racionális döntési modell és a szülöi bevonódás elméletének néhány aspektusát is megvilágítsák (körzetes iskolába, illetve emelt szintű képzésre járt-e a gyermek, a tanulóval kapcsolatos iskoláztatási tervek 6. évfolyamon, szülői segítségnyújtás a tanulmányokban, beszélgetés az iskoláról). Emellett modellünkben szerepeltettük a középiskola típusát is. Elsőként Forward Wald módszerrel lefuttattuk mindkét modellünket az előzőekben bemutatott változókkal, végső modellünkben azonban csak azokat hagytuk benne, amelyek legalább az egyik különóratípus esetében szignifikánsnak bizonyultak, az anya és az apa iskolázottsági mutatója közül pedig csak az anyáét szerepeltetjük (5. táblázat).

5. táblázat: Az idegennyelv- és matematika-különórák, magánórák igénybevétele 6. évfolyamon A bináris logisztikus regressziós modell esélyhányadosai

\begin{tabular}{|c|c|c|c|}
\hline & & $\begin{array}{c}\text { Idegen nyelv } \\
(N=75603)\end{array}$ & $\begin{array}{l}\text { Matematika } \\
(N=75591)\end{array}$ \\
\hline & & $\operatorname{Exp}(B)$ & $\operatorname{Exp}(B)$ \\
\hline A tanuló neme & fiú & 1,009 & $0,795^{\text {*** }}$ \\
\hline \multirow{3}{*}{$\begin{array}{l}\text { A lakóhely településtípusa (ref.: } \\
\text { község) }\end{array}$} & Budapest & 0,984 & $1,121^{\text {** }}$ \\
\hline & megyeszékhely & $1,158^{\star \star \star}$ & $1,287^{\star \star *}$ \\
\hline & város & $1,169^{\text {*** }}$ & $1,310^{\text {***}}$ \\
\hline \multirow{5}{*}{$\begin{array}{l}\text { Az elöző félévi tanulmányi átlag (ref.: } \\
\text { 3-as alatt) }\end{array}$} & $3,0-3,5$ & 1,126 & $0,882^{* *}$ \\
\hline & $3,6-4,0$ & 1,069 & $0,726^{* * *}$ \\
\hline & $4,1-4,5$ & 1,128 & $0,548^{* * *}$ \\
\hline & 4,5 feletti & $1,235^{* *}$ & $0,342^{* * *}$ \\
\hline & nem derül ki & $1,156^{*}$ & $0,830^{\star * *}$ \\
\hline \multirow{4}{*}{$\begin{array}{l}\text { Az anya iskolai végzettsége (ref.: } \\
\text { legfeljebb } 8 \text { osztály) }\end{array}$} & szakmunkásképző & $1,290^{* * *}$ & $1,466^{* * *}$ \\
\hline & érettségi & $1,716^{* * *}$ & $1,534^{\star * \star}$ \\
\hline & felsőfok & $2,122^{* * *}$ & $1,668^{* * *}$ \\
\hline & nem derül ki & $1,419^{* * *}$ & $1,546^{* * *}$ \\
\hline A tanuló HHH-e & igen & $0,819^{\star *}$ & $0,760^{\star * *}$ \\
\hline \multirow{3}{*}{$\begin{array}{l}\text { A szubjektív anyagi helyzet (ref.: } \\
\text { átlagnál rosszabb) }\end{array}$} & átlagos & $1,619^{* * *}$ & $1,477^{* * *}$ \\
\hline & átlag feletti & $2,546^{\star * *}$ & $2,147^{* * *}$ \\
\hline & nem derül ki & $1,681^{\star * *}$ & $1,467^{* * *}$ \\
\hline
\end{tabular}


5. táblázat: $\left(f_{\text {olyt. }}\right)$

\begin{tabular}{llcc}
\hline & & $\begin{array}{c}\text { Idegen nyelv } \\
(N=75603)\end{array}$ & $\begin{array}{c}\text { Matematika } \\
(N=75591)\end{array}$ \\
\cline { 2 - 4 } & & $\operatorname{Exp}(B)$ & $\operatorname{Exp}(B)$ \\
\hline Beszélgetés az iskoláról (ref.: szinte & ritkábban & 1,070 & $0,818^{* *}$ \\
soha) & naponta & $1,304^{* * *}$ & 1,008 \\
& nem derül ki & 0,923 & 0,992 \\
\hline Családi segítségnyújtás a házi feladat- & ritkábban & $1,084^{*}$ & 1,073 \\
ban (ref.: szinte soha) & naponta & $1,362^{* * *}$ & $1,402^{* * *}$ \\
& nem derül ki & 1,340 & 0,908 \\
\hline Az elérni kívánt iskolai végzettség & érettségi & $1,133^{*}$ & 1,002 \\
(ref. legfeljebb szakmunkásképzö) & felsőfok & $1,689^{* * *}$ & 0,990 \\
& nem derül ki & $1,455^{* * *}$ & 1,093 \\
\hline A középiskola típusa 10. évfolyamon & 6 vagy 8 évf. gimná- & 1,101 & 0,964 \\
(ref.: szakközépiskola/szakiskola) & zium & & \\
& 4 vagy 5 évf. gimná- & $1,580^{* * *}$ & $1,138^{*}$ \\
& zium & & \\
& szakgimnázium & $1,580^{* * *}$ & $1,095^{*}$ \\
& nem szerepel & $1,212^{* * *}$ & 0,953 \\
\hline & Constant & 0,018 & 0,122 \\
& -2 Log likelihood & 56087,940 & 57316,354 \\
& Cox \& Snell R Square & 0,059 & 0,024 \\
& Nagelkerke R Square & 0,108 & 0,044 \\
\hline Modellstatisztikák & & &
\end{tabular}

A szignifikanciaszint jelölése ${ }^{*} p<0,05,{ }^{* *} p<0,01,{ }^{* * *} p<0,001$

A két modell esélyhányadosai az idegennyelv-, illetve a matematika-különórák igénybevételének eltéréseit mutatják a bevont háttérváltozók mentén, a többi változó hatásának kontroll alatt tartása mellett. A jobb összevethetőség érdekében a táblázatban szerepeltetjük a nem szignifikáns változókat is, ezek az idegen nyelv esetében a tanuló neme, a fơvárosi lakóhely, míg a matematika tantárgy esetében a tanuló által elérni kívánt legmagasabb iskolai végzettség. Mindkét tantárgy esetében szignifikánsan nagyobb az esélye az iskolán kívüli különóráknak a magasabban iskolázottak körében, már a szakmunkásképzővel rendelkező édesanyák gyermekei is 1,3-1,5-szeres eséllyel vettek részt ezeken a különórákon a legfeljebb 8 általánost végzettek gyermekeihez képest. Az átlagos vagy átlag feletti családi anyagi helyzet ugyancsak növeli a valószínűségét mindkét típusú különóra igénybevételének az átlag alatti anyagi helyzethez képest. A hátrányos helyzetü gyermekek mindkét különóra fajtán kisebb eséllyel vesznek részt, mint azok, akik nem tartoznak ebbe a kategóriába. Ugyanakkor jól kirajzolódnak a különbségek is: míg ebben a korai életkorban az idegennyelv-különóra igénybevételének esélyét növeli a rendszeres szülői aktivitás a gyermek tanulmányaival kapcsolatban (napi szintü beszélgetés az iskoláról, házi feladatban nyújtott segítség), továbbá a magasabb iskoláztatási ambíciók, a ma- 
tematika esetében csak a házi feladatban nyújtott rendszeres segítség növeli a különórán való részvétel valószínüségét, az iskoláztatási ambíciók - más változókkal kontrollálva - egyáltalán nem játszanak szerepet. Ez, továbbá az a tény, hogy a matematika-különórák igénybevételének esélye szinte lineárisan csökken a félévi átlagosztályzatok kategóriái mentén, arra utal, hogy a matematika-különórák igénybevételének a legtöbb esetben a szülő tehermentesítése, illetve kisegítése lehet a célja azért, hogy a tanuló ne bukjon meg / ne maradjon le végzetesen, s a későbbiekben eredményesen tudja végezni tanulmányait. Ezzel ellentétben az idegennyelvi-különórák valószínűségét növeli, ha a gyerek jó tanuló. A tizedikes képzés típusa egyébként azt mutatja, hogy mindkét különóra választása mögött felfedezhető a racionális döntésre utaló változó hatása is, csak valószínűsíthetően más-más célokat tűznek ki az egyes különórákat választó szülők. Míg az idegen nyelvet különóraként választó családokat hipotézisünk szerint elsősorban a minél magasabb iskolai végzettség megszerzése és a kulturális tőke reprodukciójának igénye hajtja, addig a matematika-különórák esetében az iskolarendszerben való lemaradás elkerülése, az egyes szintek közötti váltások megkönnyítése lehet a legfőbb motívum, hiszen a matematika egyike azon tantárgyaknak, amelyek mindenki számára szükségesek a központi felvételi megírásakor. E hipotézis igazolására azonban olyan célzott vizsgálatok lennének szükségesek, amelyek egyebek mellett részleteiben rákérdeznek a szülői iskoláztatási célokra, stratégiákra.

\section{Összegzés}

Tanulmányunkban az Országos kompetenciamérés adatain vizsgáltuk meg a 2012-ben hatodik évfolyamra járók tanórán kívüli iskolai foglalkozásait és iskolán kívüli különóráit, követve azok alakulását egészen a tizedik évfolyamig. Az adatok azt mutatják, hogy az iskolai különórák aránya az évek elörehaladtával csökken, s bár az iskolán kívülieké az évek során ugyan stabil arányt mutat, összességében mindez azt eredményezi, hogy míg az általános iskola hatodik évfolyamán alig $14 \%$ azoknak az aránya, akik semmilyen délutáni foglalkozáson nem vesznek részt, addig tizedik évfolyamra már $36 \%$. Ezzel egyidejüleg a különféle délutáni foglalkozásokon részt vevők aránya képzési típusok szerint is jelentős eltérést mutat, a gimnáziumtól a szakközépiskolákig, szakiskolákig lineárisan csökkenő. Az iskolatípus szerepe tehát az életkor előrehaladtával egyértelműen nő a különórák igénybevételében, míg hatodik osztályban ennek még csak kisebb jelentősége van, ugyanakkor a társadalmi háttér szerinti eltérések minden életkorban jelentkeznek. Hatodik évfolyamon a településtípusnak nem annyira a délutáni foglalkozások igénybevételének tényében van szerepe, sokkal inkább arra van befolyással, hogy iskolai vagy magánórákat (is) igénybe vesz-e a tanuló. Mindemellett azonban elsődlegesen a családi hatások érvényesülnek, a szülők iskolai végzettsége mellett a szülők iskolai bevonódása is szerepet játszik abban, ha a tanuló inkább a magánkülönórákat választja. Az iskolán kívüli különórák igénybevétele tehát egyfajta szülöi stratégia része.

Ezeknek a szülői stratégiáknak a megnyilvánulása követhető nyomon akkor is, amikor a matematika- és az idegennyelvi-különórákat külön-külön vizsgáljuk. Adataink arra engednek következtetni, hogy bár mindkét esetben a tanulói életút egyengetése a cél, feltehetőleg mégis más-más helyzet húzódik meg mögöttük. Az idegennyelvi-különórák igénybevétele inkább a magasabb társadalmi státusz elérését szolgálja, $\mathrm{s}$ az átlagosnál jobb képességű, jobb társadalmi helyzetű tanulók nagyobb arányban élnek vele, míg a 
matematika-különóra igénybevétele társadalmi háttér szerint „demokratikusabb” és funkciójában sokkal inkább a felzárkóztatás, a gyakoroltatás a célja annak érdekében, hogy a gyermek sikeresen tudja bevenni a következő iskolafokot.

\section{IRODALOM}

Andor M. \& Liskó I. (1999) Iskolaválasztás és mobilitás. Budapest, Iskolakultúra.

Bourdieu, P. (1978) A társadalmi egyenlötlenségek újratermelödése. Budapest, Gondolat.

Bray, M. (1999) The Shadow Education System. Private Tutoring and Its Implications for Planners. Paris, United Nations Educational, Scientific and Cultural Organization.

Bray, M. (2007) Confronting the Shadow Education System. What Government Policies for What Private Tutoring? Paris, IIEP Policy Forum. UNESCO Publishing.

Bray, M. \& Kobakhidze, M. N. (2014) Measurement Issues in Research on Shadow Education: Challenges and Pitfalls Encountered in TIMSS and PISA. Comparative Education Review, Vol. 58. No. 4. pp. 590-620.

Breen, R. \& Goldthorpe, J. H. (1997) Explaining Educational Differentials: Towards a Formal Rational Action Theory. Rationality and Society, Vol. 9. No. 3. pp. 275-305.

Ceglédi T. \& Szabó A. É. (2014) Középiskolások és hallgatók az árnyékoktatásban. In: Ceglédi T., Gál A. \& Nagy Z. (eds) Határtalan oktatáskutatás. Tanulmányok a 75 éves Kozma Tamás tiszteletére. Debrecen, Debreceni Egyetem Felsőoktatási Kutató és Fejlesztő Központ. pp. 257-274.

Collas, T. \& Jacobs, A. (2013) Users of Private Tutoring in France: Varieties of Scholastic Support and Family Shaping of Education. Revue Française de Sociologie (English Edition), Vol. 54. No. 3. pp. 463-502.

Entrich, S. R. (2014) Effects of Investments in Out-of-school Education in Germany and Japan. Contemporary Japan, Vol. 26. No. 1. pp. 71-102.

Entrich, S. R. (2015) The Decision for Shadow Education in Japan: Students' Choice or Parents' Pressure? Social Science Japan Journal, Vol. 18. No. 2. pp 193-216.

Erikson, R. \& Jonsson, J. O. (1996) Explaining Class Inequality in Education: The Swedish Test Case. In: R. Erikson \& J. O. Jonsson (eds) Can Education Be Equalised? The Swedish Case in Comparative Perspective. Boulder, Westview Press. pp. 1-63.

Hörich B. (2019) Tanulási utak a társadalmi háttér függvényében. Educatio, Vol. 28. No. 4. pp. 659-682.

Lareau, A. (2000) Social Class and the Daily Lives of Children. A Study from the United States. Childhood: A Global Journal of Child Research, Vol. 7. No. 2. pp. 155-171.

PARK, H., Byun, S. \& KIm, K. (2011) Parental Involvement and Students' Cognitive Outcomes in Korea. Focusing on Private Tutoring. Sociology of Education, Vol. 84. No. 1. pp. 3-22.

Reay, D. (2004) Education and Cultural Capital: The Implications of Changing Trends in Education Policies. Cultural Trends, Vol. 13. No. 2. pp. 73-86.

Reay, D. \& BAll, S. J. (1997) ,Spoilt for Choice': The Working Classes and Educational Markets. Oxford Review of Education, Vol. 23. No. 1. pp. 89-101.

Safarzyńska, K. (2013) Socio-economic Determinants of Demand for Private Tutoring. European Sociological Review, Vol. 29. No. 2. pp. 139-154.

Silova, I. (2010) Private Tutoring in Eastern Europe and Central Asia: Policy Choices and Implications. Compare, Vol. 40. No. 3. pp. 327-344. https://www.researchgate.net/ 
publication/48140047_Private_tutoring_in_Eastern_Europe_and_Central_Asia_ Policy_choices_and_implications [Letöltve: 2020.05.21.]

Szemerszki M. (2015) A tanulói eredményesség dimenziói és háttértényezői. In:

Szemerszki M. (ed.) Eredményesség az oktatásban. Dimenziók és megközelitések. Budapest, OFI. pp. 52-87.

Szemerszki M. (2016) A tanulói továbbhaladás egyéni és intézményi jellemzői. In:

Szemerszki M. (ed.) Hátrányos belyzet és iskolai eredményesség. Budapest, OFI. pp. 29-51.

\section{MELLÉKLET}

1. táblázatः Külön foglalkozások igénybevétele különböző tanulói csoportokban (6. évfolyam, $N=76714$ )

\begin{tabular}{|c|c|c|c|c|c|}
\hline & & $\begin{array}{c}\text { Nem vesz } \\
\text { igénybe (\%) }\end{array}$ & $\begin{array}{c}\text { Csak iskolai } \\
\text { (\%) }\end{array}$ & $\begin{array}{l}\text { Csak magán } \\
(\%)\end{array}$ & $\begin{array}{l}\text { Magán és } \\
\text { iskolai is (\%) }\end{array}$ \\
\hline \multirow[t]{2}{*}{ Az iskola típusa ${ }^{* * *}$} & általános iskola & 13,9 & 28,9 & 14,8 & 42,4 \\
\hline & $\begin{array}{l}8 \text { évfolyamos gim- } \\
\text { názium }\end{array}$ & 10,4 & 11,1 & 32,4 & 46,1 \\
\hline \multirow[t]{2}{*}{ A tanuló osztálya ${ }^{* * *}$} & normál tantervű & 14,3 & 30,6 & 13,6 & 41,4 \\
\hline & $\begin{array}{l}\text { emelt szintủ, kéttan- } \\
\text { nyelvű, nemzetiségi }\end{array}$ & 12,2 & 21,1 & 20,6 & 46,1 \\
\hline \multirow{6}{*}{$\begin{array}{l}\text { Előző félévi tanul- } \\
\text { mányi átlag }\end{array}$} & 3 -as alatti & 14,4 & 45,3 & 4,8 & 35,5 \\
\hline & $3,0-3,5$ & 15,0 & 36,9 & 8,3 & 39,8 \\
\hline & $3,6-4,0$ & 15,2 & 28,9 & 13,4 & 42,5 \\
\hline & $4,1-4,5$ & 14,7 & 22,5 & 19,2 & 43,6 \\
\hline & 4,5 feletti & 9,7 & 18,6 & 23,3 & 48,3 \\
\hline & nem derül ki & 16,2 & 31,4 & 13,8 & 38,5 \\
\hline \multirow{4}{*}{$\begin{array}{l}\text { A tanuló lakóhe- } \\
\text { lye } e^{* * *}\end{array}$} & Budapest & 9,6 & 19,3 & 23,3 & 47,8 \\
\hline & megyeszékhely & 13,6 & 22,1 & 21,9 & 42,4 \\
\hline & város & 14,4 & 27,2 & 15,2 & 43,2 \\
\hline & község & 14,7 & 35,1 & 10,0 & 40,2 \\
\hline \multirow[t]{2}{*}{ A tanuló neme $e^{* * *}$} & lány & 14,4 & 27,4 & 16,8 & 41,5 \\
\hline & fiú & 13,2 & 29,0 & 14,2 & 43,6 \\
\hline \multirow[t]{2}{*}{ A tanuló $\mathrm{HHH}-\mathrm{e}^{\star \star *}$} & igen & 16,8 & 45,4 & 4,3 & 33,5 \\
\hline & nem & 13,4 & 25,8 & 17,0 & 43,7 \\
\hline \multirow{5}{*}{$\begin{array}{l}\text { Az anya iskolai } \\
\text { végzettsége }^{\star \star *}\end{array}$} & legfeljebb 8 általános & 17,9 & 44,7 & 5,3 & 32,1 \\
\hline & szakmunkásképző & 16,7 & 34,2 & 9,9 & 39,2 \\
\hline & érettségi & 13,6 & 23,9 & 17,6 & 44,9 \\
\hline & felsőfokú & 7,3 & 13,0 & 27,7 & 52,1 \\
\hline & nem derül ki & 15,0 & 31,1 & 14,5 & 39,3 \\
\hline
\end{tabular}


1. táblázat: $\left(f_{0} l y t\right.$.)

\begin{tabular}{|c|c|c|c|c|c|}
\hline & & $\begin{array}{l}\text { Nem vesz } \\
\text { igénybe (\%) }\end{array}$ & $\begin{array}{c}\text { Csak iskolai } \\
(\%)\end{array}$ & $\begin{array}{l}\text { Csak magán } \\
\text { (\%) }\end{array}$ & $\begin{array}{l}\text { Magán és } \\
\text { iskolai is (\%) }\end{array}$ \\
\hline \multirow{5}{*}{$\begin{array}{l}\text { Az apa iskolai vég- } \\
\text { zettsége*** }^{* *}\end{array}$} & legfeljebb 8 általános & 17,8 & 43,4 & 5,4 & 33,4 \\
\hline & szakmunkásképző & 15,8 & 32,3 & 11,4 & 40,4 \\
\hline & érettségi & 11,6 & 21,6 & 19,9 & 46,8 \\
\hline & felsőfokú & 7,6 & 11,5 & 29,0 & 51,9 \\
\hline & nem derül ki & 16,3 & 34,4 & 12,9 & 36,3 \\
\hline \multirow{4}{*}{$\begin{array}{l}\text { A család anyagi } \\
\text { helyzete (szubjektív } \\
\text { érzékelés) }{ }^{* * *}\end{array}$} & átlagnál rosszabb & 16,9 & 39,9 & 8,9 & 34,3 \\
\hline & átlagos & 13,8 & 27,1 & 15,7 & 43,4 \\
\hline & átlag feletti & 8,8 & 15,3 & 23,9 & 52,1 \\
\hline & nem derül ki & 15,8 & 28,2 & 20,1 & 35,9 \\
\hline \multirow{4}{*}{$\begin{array}{l}\text { Családi segítségnyúj- } \\
\text { tás a házi feladat- } \\
\text { ban }^{* * *}\end{array}$} & szinte soha & 18,2 & 30,6 & 14,8 & 36,3 \\
\hline & ritkábban & 13,6 & 27,4 & 16,5 & 42,5 \\
\hline & naponta & 12,2 & 28,5 & 14,0 & 45,4 \\
\hline & nem derül ki & 19,1 & 30,9 & 16,5 & 33,5 \\
\hline \multirow{4}{*}{$\begin{array}{l}\text { Beszélgetés az isko- } \\
\text { láról }^{* * *}\end{array}$} & szinte soha & 20,4 & 35,7 & 10,9 & 33,0 \\
\hline & ritkábban & 17,2 & 31,6 & 13,4 & 37,8 \\
\hline & naponta & 12,6 & 26,9 & 16,2 & 44,3 \\
\hline & nem derül ki & 20,1 & 29,7 & 17,1 & 33,1 \\
\hline \multirow{2}{*}{$\begin{array}{l}\text { Körzetes iskolába jár- } \\
\text { e a tanuló*** }\end{array}$} & igen & 14,4 & 31,7 & 12,1 & 41,8 \\
\hline & nem & 12,5 & 20,9 & 22,5 & 44,1 \\
\hline \multirow[t]{4}{*}{$\begin{array}{l}\text { Az elérni kívánt } \\
\text { iskolai végzettség*** }\end{array}$} & $\begin{array}{l}\text { legfeljebb } \\
\text { szakmunkásképző }\end{array}$ & 15,6 & 45,7 & 4,8 & 33,9 \\
\hline & érettségi & 16,8 & 33,7 & 10,3 & 39,2 \\
\hline & felsőfok & 11,1 & 19,0 & 22,3 & 47,6 \\
\hline & nem derül ki & 15,4 & 30,1 & 15,1 & 39,4 \\
\hline Összesen & & 13,8 & & 28,2 & 42,5 \\
\hline
\end{tabular}

A cikk a Creative Commons Attribution 4.0 International License (https://creativecommons.org/licenses/ by/4.0/) feltételei szerint publikált Open Access közlemény, melynek szellemében a cikk bármilyen médiumban szabadon felhasználható, megosztható és újraközölhető, feltéve, hogy az eredeti szerző és a közlés helye, illetve a CC License linkje és az esetlegesen végrehajtott módosítások feltüntetésre kerülnek. (SID_1) 